Louisiana State University

LSU Digital Commons

$9-1-2006$

\title{
Proteomic and genetic approaches to identifying defence-related proteins in rice challenged with the fungal pathogen Rhizoctonia solani
}

Joohyun Lee

LSU Agricultural Center

Terry M. Bricker

Louisiana State University

Michael Lefevre

Pennington Biomedical Research Center

Shannon R.M. Pinson

USDA Agricultural Research Service, Washington DC

James H. Oard

LSU Agricultural Center

Follow this and additional works at: https://digitalcommons.Isu.edu/biosci_pubs

\section{Recommended Citation}

Lee, J., Bricker, T., Lefevre, M., Pinson, S., \& Oard, J. (2006). Proteomic and genetic approaches to identifying defence-related proteins in rice challenged with the fungal pathogen Rhizoctonia solani. Molecular Plant Pathology, 7 (5), 405-416. https://doi.org/10.1111/j.1364-3703.2006.00350.x 


\title{
Proteomic and genetic approaches to identifying defence-related proteins in rice challenged with the fungal pathogen Rhizoctonia solani
}

\author{
JOOHYUN LEE ${ }^{1, *}$, TERRY M. BRICKER ${ }^{2}$, MICHAEL LEFEVRE ${ }^{3}$, SHANNON R. M. PINSON ${ }^{4}$ AND \\ JAMES H. OARD ${ }^{1}$ \\ 1 Department of Agronomy and Environmental Management, LSU AgCenter, 104 M.B. Sturgis Hall, \\ ${ }^{2}$ Department of Biological Sciences, and \\ ${ }^{3}$ Pennington Biomedical Research Center, Louisiana State University, Baton Rouge, LA 70803, USA; \\ ${ }^{4}$ USDA-ARS Rice Research Unit, 1509 Aggie Drive, Beaumont, TX 77713, USA
}

\section{SUMMARY}

Sheath blight, caused by the fungus Rhizoctonia solani, is a major disease of rice world-wide, but little is known about the host response to infection. The objective of this study was to identify proteins and DNA markers in resistant and susceptible rice associated with response to infection by $R$. solani. Replicated two-dimensional polyacrylamide gel electrophoresis experiments were conducted to detect proteins differentially expressed under inoculated and non-inoculated conditions. Tandem mass spectra analysis using electrospray ionization quadrupole-time of flight mass spectrometry (ESI Q-TOF MS) was carried out for protein identification with the NCBI non-redundant protein database. Seven proteins were increased after inoculation in both susceptible and resistant plants. Six of the seven proteins were identified with presumed antifungal, photosynthetic and proteolytic activities. An additional 14 proteins were detected in the response of the resistant line. Eleven of the 14 proteins were identified with presumed functions relating to antifungal activity, signal transduction, energy metabolism, photosynthesis, molecular chaperone, proteolysis and antioxidation. The induction of 3- $\beta$-hydroxysteroid dehydrogenase/isomerase was detected for the first time in resistant rice plants after pathogen challenge, suggesting a defensive role of this enzyme in rice against attack by $R$. solani. The chromosomal locations of four induced proteins were found to be in close physical proximity to genetic markers for sheath blight resistance in two genetic mapping populations. The proteomic and genetic results from this study indicate a complex response of rice to challenge by $R$. solani that involves simultaneous induction of proteins from multiple defence pathways.

* Correspondence and present address: Soybean Genomics and Improvement Laboratory, USDA-ARS, 10300 Baltimore Ave., Bldg. 006, Rm. 201, Beltsville, MD 20705, USA. Tel.: +1 301504 5537; Fax: +1 301504 5728; E-mail: leejo@ba.ars.usda.gov.

\section{INTRODUCTION}

Rice (Oryza sativa L.) is considered a model crop plant owing to its importance world-wide as a food source (Sasaki and Burr, 2000), a small diploid genome suitable for genetic and molecular analyses (Devos and Gale, 2000), and available transgene technology (Hiei et al., 1994). Completion of the draft rice genome sequence (Goff et al., 2002) has encouraged researchers to focus on identity, function and regulation of genes on a genome-wide scale. Because proteins are key components of structure and play vital roles in the cell, proteomic analysis can ideally provide direct functional information by exploring the global expression patterns of proteins in various states (Rakwal and Agrawal, 2003). Rice proteomics research has made considerable progress recently in providing functional information of proteins expressed in the various developmental stages, tissues, cells, and abiotic and biotic stress environments (Komatsu and Tanaka, 2004). For example, a recent proteomic study using two-dimensional polyacrylamide gel electrophoresis (2-DE PAGE) and multidimensional protein identification technology (MudPIT) detected over 25000 peptides and 2500 unique proteins belonging to various biochemical pathways from rice leaf, root and seed sources (Koller et al., 2002). A rice anther proteome map has been constructed that contains over 4000 protein spots presented in 2-D gels within the pl range 4-11 with molecular weights of 6-122 kDa, corresponding to $10 \%$ of the rice genome (Imin et al., 2001). A comprehensive rice proteome database was recently constructed that contains 11941 identified proteins and 21 reference proteome maps based on 2-DE PAGE, including various rice tissues and subcellular compartments (Komatsu and Tanaka, 2004). The primary focus of rice proteomic research to date has centred on detection and characterization of proteins in response to biotic and abiotic stresses. Rakwal and Komatsu (2000) investigated rice seedlings after treatment by jasmonic acid (JA), and detected induction of various proteins including pathogenesis-related proteins (PR-proteins) involved in stress response, supporting a role of JA in the rice 
defence system. Shen et al. (2003) monitored changes in the rice leaf sheath proteome responding to physical wounding and observed decreased proteins associated with protein folding, and oxygen transfer while also detecting induced proteins associated with protease inhibition, signal transduction, photosynthesis and abiotic stress. Konishi et al. (2001) observed that PR-5 was induced by infection of the leaf blade by the pathogen Magnaporthe grisea, and the level of ribulose-1,5-bisphospate carboxylase/ oxigenase (RuBisCO) proteins was modified depending on the specific amount of nitrogen fertilizer applied to the soil. S. T. Kim et al. (2003) reported induction of various proteins including rice PR proteins and salt-inducible proteins related to general stress responses and regulatory enzymes in suspension-cultured rice cells after inoculation with $M$. grisea and defence-inducing elicitors $J A$, salicylic acid $(\mathrm{SA})$ and hydrogen peroxide $\left(\mathrm{H}_{2} \mathrm{O}_{2}\right)$. Brassinosteroid (BR), the most well-known plant steroid hormone, has been reported to play a role in cold stress response of rice seedlings (Hotta et al., 1998), and in resistance to the pathogens M. grisea and Xanthomonas oryzae pv. oryzae (Nakashita et al., 2003).

Sheath blight disease, caused by Rhizoctonia solani, is a major constraint to high grain yield and quality in many rice-growing regions of the world (Marshall and Rush, 1980). R. solani is believed to secrete various toxins, the most notable of which is the RS phytotoxin, a carbohydrate molecule containing glucose, mannose, $\mathrm{N}$-acetylgalactosamine and $\mathrm{N}$-acetylglucosamine (Vidhyasekaran et al., 1997). General symptoms of sheath blight include necrotic, dark, reddish-brown, elliptical or oval-shaped areas on the leaf sheath, leaf blade and culm (Lee and Rush, 1983). Modern semi-dwarf varieties in the US and elsewhere are normally grown at high densities that create a favourable environment for development of sheath blight (Lee and Rush, 1983). Most varieties grown around the world are susceptible to $R$. solani, although moderate to high levels of tolerance have been reported (Pan et al., 1999). The somaclonal mutant LSBR-5 (Xie et al., 1992), selected from the sheath blight-susceptible variety Labelle (Marshall and Rush, 1980), has shown high levels of resistance both in greenhouse and field studies (Xie et al., 1992). Genetic control of resistance in LSBR-5 was reported to be controlled by a single recessive gene (Xie et al., 1992). Previous genetic mapping studies have identified quantitative trait loci (QTL) and individual markers associated with sheath blight resistance in a population of recombinant inbred lines (RILs) (Pinson et al., 2005; Pinson, Oard and Capdevielle, unpublished data).

Even though sheath blight disease exerts a substantial impact on rice production in many regions of the world, limited information is available on response to infection by $R$. solani at the protein or genetic level. The primary objectives of this research were to monitor the global defence response of rice leaf sheath proteins to $R$. solani infection and to identify candidate proteins and associated DNA markers that can serve in future studies of rice-fungal interactions and in development of new, diseaseresistant varieties. We also report here for the first time that 3- $\beta$-hydroxysteroid dehydrogenase was induced in resistant rice after infection by $R$. solani, suggesting that this enzyme may play a role in synthesis and regulation of steroids associated with disease resistance.

\section{RESULTS}

\section{2-DE PAGE analysis and protein identification}

Approximately 1000 protein spots stained with Sypro-Ruby (Bio-Rad, Hercules, CA) were reproducibly resolved on all 24 2-D gels used in the comparison analysis, which consisted of three subreplications of a protein sample, two treatments of infection (inoculation vs. non-inoculation), two biological replications and two rice strains (resistant vs. susceptible). Protein spots were reproducibly resolved across all gels, resulting in similar protein spot locations across replications (Fig. 1). With PDQUEST (Bio-Rad) image analysis software, 21 protein spots were detected whose relative abundance varied in the response of the resistant LSBR-5 (Fig. 2) or susceptible Labelle to $R$. solani infection. Seven increased protein spots were detected in the response of susceptible Labelle, and 14 additional protein spots (11 increased, three decreased) were detected in the response of resistant LSBR-5 (Fig. 3). Seventeen out of 21 detected protein spots were identified through the MASCOT MS/MS ion search engine with MS/MS spectra produced by Q-TOF (Waters, Milford, MA). At least two peptides were identified from MS/MS spectra for protein identification, except protein spots 8,9 , and 14 , for which a single peptide was identified for each one consisting of at least ten amino acid residues (Tables 1 and 2).

Six of the seven identified proteins whose relative abundance varied significantly in the resistant and susceptible lines are detailed in Table 1 with protein name, NCBI accession number and identity scores. For example, $\beta-1,3$-glucanase was increased in both the resistant and the susceptible lines, but the protein abundance ratio for the inoculated/non-inoculated treatments in the mutant line was twofold greater than the corresponding treatments applied to the susceptible plant line. In addition, the relative amount of protein detected in the inoculated resistant line was 2.5-4-fold greater when compared with the inoculated Labelle or non-inoculated LSBR-5. No differences in protein amounts were observed between non-inoculated LSBR- 5 and non-inoculated Labelle. A similar treatment response and relative protein abundance pattern were observed for the $20 \mathrm{~S}$ proteasome $\beta$-subunit and the 265 proteosome non-ATPase regulatory subunit. Relative abundance of three distinct RuBisCO large subunits and a precursor were detected in the inoculated LSBR-5 at 2-3-fold higher levels than in the corresponding susceptible Labelle treatments. 


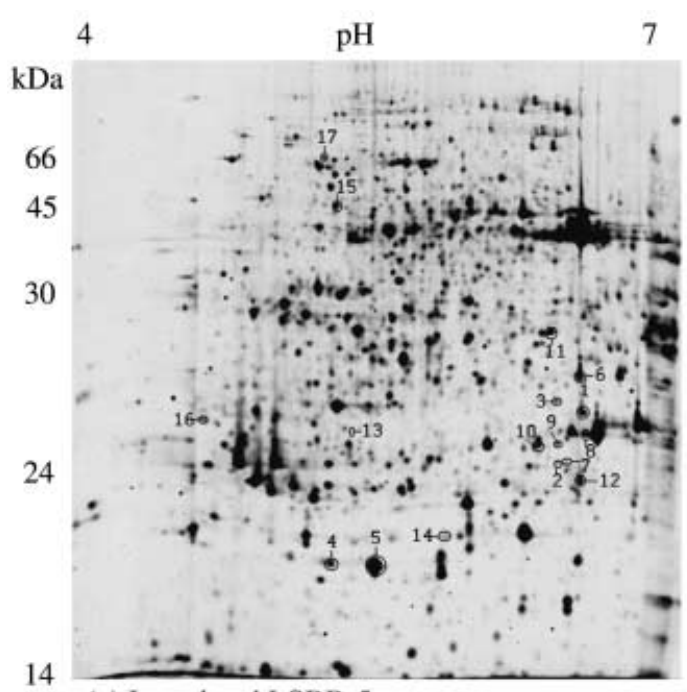

(a) Inoculated LSBR-5

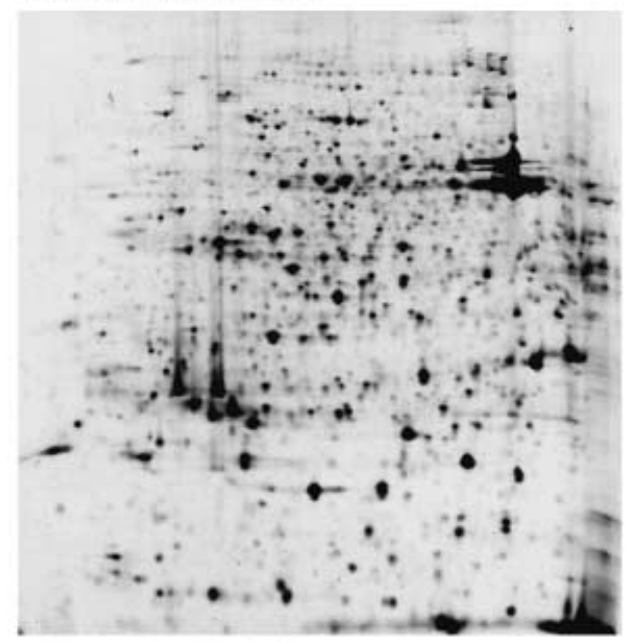

(c) Inoculated Labelle

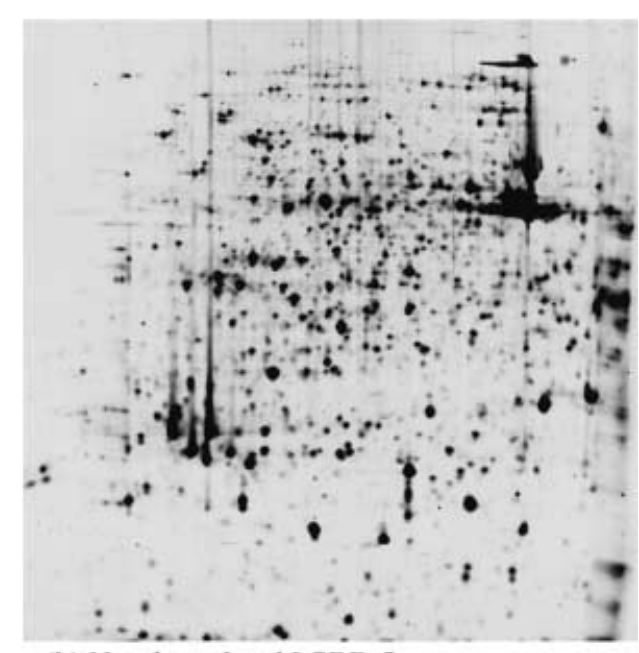

(b) Non-inoculated LSBR-5

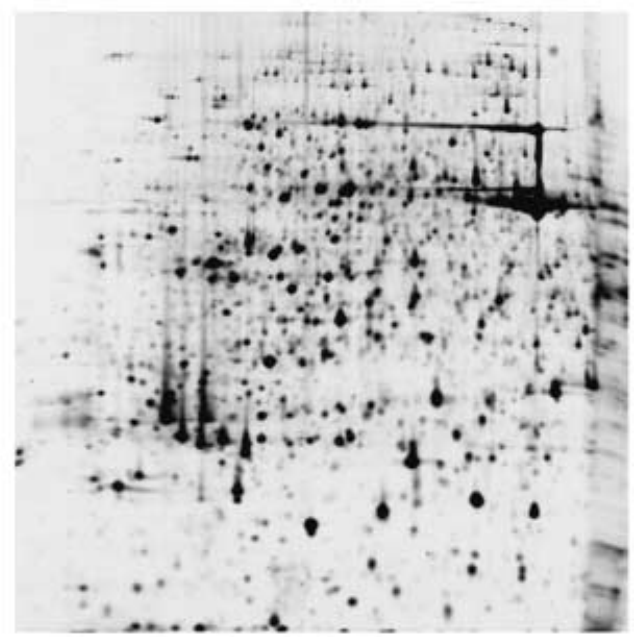

(d) Non-inoculated Labelle

Fig. 1 Sypro-Ruby-stained 2-DE PAGE gels of rice leaf sheath proteins extracted from inoculated and non-inoculated resistant and susceptible lines. Proteins were separated with an IPG strip, pH 4-7, and 12\% linear polyacrylamide LDS-PAGE. Gel images were acquired with an FX scanner (Bio-Rad). Circled proteins were identified by ESI-Q-TOF mass spectrometry. Spot numbers were assigned in an arbitrary fashion.

The relative abundance of 11 of 14 identified proteins that varied only in response of the resistant line to infection by $R$. solani is given in Table 2 . The plant steroid-related 3- $\beta$-hydroxysteriod dehydrogenase/isomerasae (3- $\beta$ HSD) was detected at threefold higher levels in inoculated vs. non-inoculated LSBR- 5 and twofold higher levels in inoculated resistant vs. susceptible lines. No significant differences were found between infected vs. noninfected Labelle or non-inoculated treatments of the two lines. Three- to fivefold higher levels of two chitinase isoforms were detected in the inoculated vs. non-inoculated treatments of LSBR-5 and at twofold higher levels in the infected resistant vs. infected susceptible lines. RuBisCO large subunit and RuBisCO activase were induced at 4-5-fold higher levels in the inoculated vs. non-inoculated LSBR-5 and at threefold higher levels in the inoculated resistant vs. susceptible line. Similar treatment responses were detected for glyceradehyde 3-phosphate dehydrogenase (GAPDH) $\alpha$ subunit, 20S proteasome $\alpha-1$ subunit and stromal ascorbate peroxidase (SAPX). Decreased protein spots were detected with infected LSBR-5 for putative chaperonin 60 beta precursor, 14-3-3-like protein and endosperm lumenal binding protein. Relative amounts of these proteins were at less than twofold lower levels in inoculated resistant LSBR-5.

\section{Genetic and physical map of markers and proteins for response to $R$. solani}

QTL regions and molecular markers previously mapped to three chromosomes associated with sheath blight resistance among a 
(a)

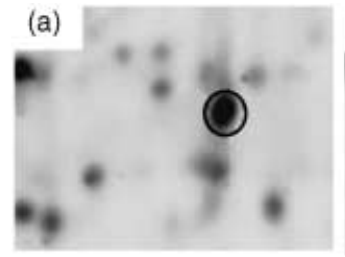

(e)

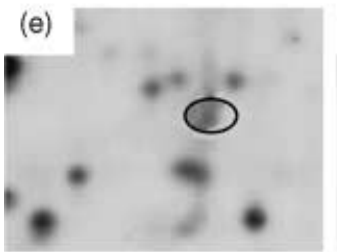

(b)

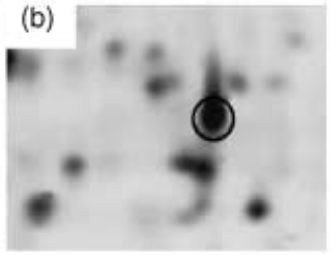

(f)

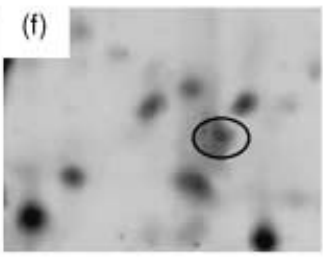

(c)
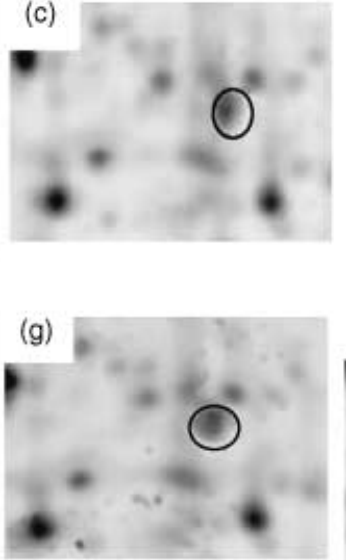
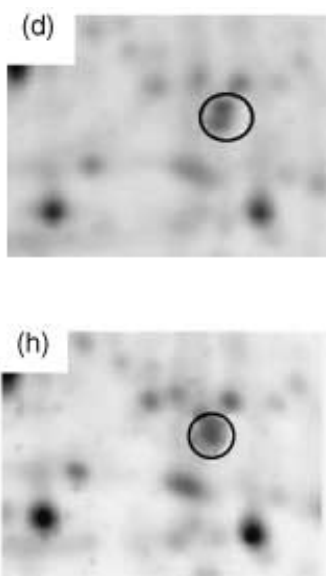

Fig. 2 Relative abundance of alpha 1 subunit of 20S proteasome detected in inoculated and non-inoculated LSBR-5 and Labelle. (a,b) Gels of inoculated LSBR-5 from two independent biological replications. (c,d) Gels of inoculated Labelle from two independent biological replications. (e,f) Gels of non-inoculated LSBR-5 from two independent biological replications. $(\mathrm{g}, \mathrm{h}) \mathrm{Gels}$ of non-inoculated Labelle from two independent biological replications.

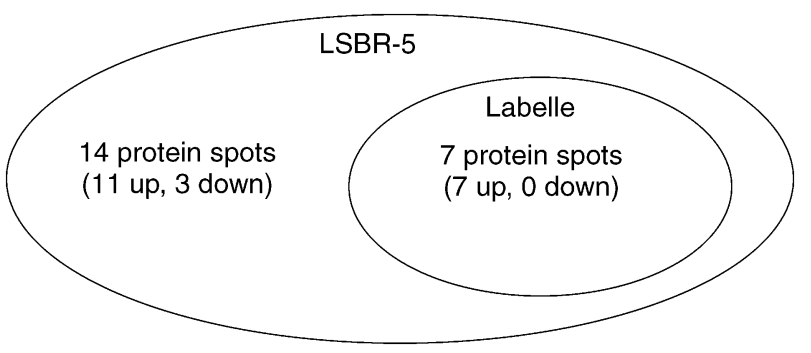

Fig. 3 Venn diagram of increased or decreased proteins in response of resistant LSBR-5 and susceptible Labelle infected by $R$. solani.

population of RILs (Pinson et al., 2005) and $\mathrm{F}_{4}$ families (Li et al., 1995) are shown in Fig. 4. Marker alleles detected by discriminant analysis and step-wise regression (Pinson, Oard and Capdevielle, unpublished data) were included relative to the genetic regions of QTL and to the physical location of four proteins detected in this study. The QTL and discriminant/step-wise DNA markers mapped to the same or nearby regions for sheath blight resistance from two populations on chromosomes 2, 3 and 5. Based on release 3 of the TIGR pseudomolecule genomic database (http://www.tigr.org), the gene encoding SAPX detected in this study was located at a position within a previously defined QTL region (Li et al., 1995) on chromosome 2 (Fig. 4) and separated by $\sim 429000$ bp or $\sim 2 \mathrm{cM}$ from the marker $\mathrm{C} 624 \mathrm{x}$, selected by discriminant analysis and step-wise regression (Pinson, Oard and Capdevielle, unpublished data). Genes encoding the chitinase and GAPDH enzymes detected in this study were found at positions on chromosome 3 within QTL regions identified in two separate populations (Li et al., 1995; Pinson, Oard and Capdevielle, unpublished data). The two genes were located $\sim 200000-$ 430000 bp or 1-2 cM from the marker RG348, selected both by discriminant and by step-wise regression methods to be associated with sheath bight resistance (Pinson, Oard and Capdevielle, unpublished data). Finally, the phenotypic marker $g l-1$ (glabrous leaf), selected by discriminant and step-wise regression methods, mapped $9 \mathrm{cM}$ from the marker RG556 on chromosome 5 that in turn was located $\sim 105000$ bp or $<1$ cM from 3- $\beta$ HSD identified in this study.

\section{DISCUSSION}

\section{Comparison between response of resistant LSBR- 5 and response of susceptible Labelle to $R$. solani}

Unlike other proteomic research on plant response to pathogens, this study was focused on the proteome response of rice leaf sheath adjacent to the infected areas. Although the direct interaction and response against the infection occurs in the infected area, it can be impossible to distinguish the response between rice proteome and $R$. solani proteome when the proteins from $R$. solani have homology with rice proteins owing to the fact that the protein and nucleotide database of $R$. solani is limited and the protein identification method with MS technology used in this study is absolutely dependent on the protein and nucleotide database. However, with the 2-DE proteomic approach on the rice leaf sheath adjacent to the infected area, we were able to detect reproducible proteome differences between the host response of the resistant mutant line LSBR- 5 and that of the susceptible Labelle. The study revealed that seven out of the 21 identified proteins showed significant variation in relative abundance after pathogen challenge of the resistant LSBR- 5 and the susceptible Labelle. A common stress response system appeared to be activated in both resistant and susceptible lines, but the resistant LSBR-5 line produced significantly larger amounts of 
Table 1 Identified proteins whose relative abundance varied significantly in the resistant line LSBR-5 and the susceptible line Labelle with infection by $R$. solani.

\begin{tabular}{|c|c|c|c|c|c|c|c|c|c|}
\hline \multirow{2}{*}{$\begin{array}{l}\text { Spot } \\
\text { no. }\end{array}$} & \multirow[b]{2}{*}{ Name } & \multirow{2}{*}{$\begin{array}{l}\text { Accession } \\
\text { no. }\end{array}$} & \multirow{2}{*}{$\begin{array}{l}\text { No. of } \\
\text { peptides* }\end{array}$} & \multirow{2}{*}{$\begin{array}{l}\text { Sequence } \\
\text { coveraget (\%) }\end{array}$} & \multirow[b]{2}{*}{ Scoreł } & \multicolumn{4}{|c|}{ Ratio of relative abundance§ } \\
\hline & & & & & & IL/NLף & I5/N5** & I5/IL & $\mathrm{N} 5 / \mathrm{NL}$ \\
\hline 1 & $\beta$-1,3-glucanase [Oryza sativa] & gi|4884530 & 4 & 12 & 253 & $2.16 \pm 0.07$ & $3.90 \pm 1.20$ & $2.50 \pm 0.27$ & NSt† \\
\hline 2 & $\begin{array}{l}20 S \text { proteasome beta subunit } \\
\text { [Oryza satita ( japonica cultivar-group)] }\end{array}$ & gi|50933089 & 2 & 7 & 83 & $1.53 \pm 0.05$ & $3.28 \pm 1.13$ & $1.50 \pm 0.05$ & NS \\
\hline 3 & $\begin{array}{l}\text { Putative } 265 \text { proteasome non-ATPase } \\
\text { regulatory subunit } 14 \text { [Oryza sativa } \\
\text { (japonica cultivar-group)] }\end{array}$ & gi|54287494 & 4 & 16 & 142 & $2.28 \pm 0.26$ & $4.43 \pm 1.26$ & $2.39 \pm 0.52$ & NS \\
\hline 4 & Rubisco large subunit & gi|476752 & 3 & 9 & 190 & $1.68 \pm 0.01$ & $2.11 \pm 0.05$ & $2.27 \pm 0.01$ & NS \\
\hline 5 & Rubisco large subunit & gi|476752 & 3 & 9 & 113 & $2.00 \pm 0.14$ & $5.16 \pm 1.13$ & $2.07 \pm 0.87$ & NS \\
\hline 6 & $\begin{array}{l}\text { Ribulose-bisphosphate carboxylase } \\
\text { (EC 4.1.1.39) large chain precursor-rice } \\
\text { chloroplast [Oryza sativa] }\end{array}$ & gi|7436576 & 3 & 9 & 128 & $2.03 \pm 0.48$ & $4.13 \pm 0.98$ & $2.30 \pm 0.18$ & NS \\
\hline
\end{tabular}

*Number of peptides identified from MS/MS spectra.

†Percentage of sequence coverage of identified peptides for protein.

$\neq$ Score $=-10 \times \log (P)$, where $P$ is the probability that the observed match with a given MS/MS spectra is a random event. Thus, a high score indicates identity or extensive homology.

$\S$ Ratios of relative abundance are presented as means \pm SD $(n=2)$. The ratios were calculated by dividing the relative abundance of a protein spot in one treatment by the relative abundance of a protein spot in the corresponding treatment. A value greater than 1 represents an increased protein, whereas a ratio less than 1 represents a decreased protein.

IIL, inoculated Labelle; NL, non-inoculated Labelle.

**I5, inoculated LSBR-5; N5, non-inoculated LSBR-5.

††NS, non-significant.

those proteins described in Table 1. All six of these identified proteins have been previously reported as being involved in disease response (Basset et al., 2002; Bera and Purkayastha, 1997; Konish et al., 2001), which suggests a common baseline defence strategy for different host-parasite interactions. For example $\beta-1-3$ glucanase, which enhances antifungal activity by degrading the fungus cell wall, was increased to a higher level in the resistant vs. the susceptible line. The phenomenon of induction of defence-related proteins was previously reported in the interaction between Aradopsis thaliana and the fungus Peronospora parasitica (Maleck et al., 2000). In the current study, seven proteins detected in both responses were increased to a significantly higher level in LSBR-5 than in Labelle, and an additional 14 proteins (Table 2), whose quantities did not vary in the response for Labelle, showed significant quantitative variation in the response of LSBR-5. Proteins identified with higher induced levels in LSBR-5 than in Labelle were previously reported as being involved in disease reactions (Asada, 1992; Broglie et al., 1991; Finnie et al., 2002; Lorimer, 1996; Shen et al., 2003; Umeda and Uchimiya, 1994). From the different protein expression patterns detected in this study, it is hypothesized that the resistance of LSBR-5 resulted from the ability to produce greater amounts of defence proteins than the susceptible Labelle, and this ability was possibly controlled by key regulatory protein(s) acquired during in vitro somaclonal culture of the resistant LSBR-5 mutant.

\section{Identified proteins in response of rice leaf sheath to R. solani}

Results indicated that $3-\beta$ HSD was increased only in the resistant line. To our knowledge, this is the first report of induction of $3-\beta$ HSD in response of rice to pathogen infection. Mutations of $3-\beta$ HSD in humans have been associated with the onset of childhood disease via disruption of the cholesterol biosynthetic pathway (Konig et al., 2000) and with congenital adrenal hyperplasia (Rheaume et al., 1994). This enzyme was reported in plants to play a role in the formation of cardinolides in Grecian foxglove (Digitalis lanata) (Finsterbusch et al., 1999). Milkweed produces cardenolide, which is toxic to insects, in the leaf as a putative defence mechanism against sucking insect herbivores (Martel and Malcolm, 2004). The occurrence of 3- $\beta$ HSD enzyme activity in Solanum tuberosum and Nicotiana tabacum plants, which are unable to form cardenolides, implies that this enzyme may be involved in other steroid metabolic functions (Seidel et al., 1990). In recent proteomic research of ginseng (Panax ginseng), 3- $\beta$ HSD was reported to be induced by high light conditions ( $\mathrm{Nam}$ et al., 2003). Results from our study suggest that $3-\beta$ HSD may be involved in the synthesis or regulation of plant steroids associated with host defence, but further investigations will be required to elucidate the exact role of this protein in the rice- $R$. solani interaction. 
Table 2 Identified proteins whose relative abundance varied significantly only in response of resistant LSBR-5 with infection by $R$. solani.

\begin{tabular}{|c|c|c|c|c|c|c|c|c|c|}
\hline \multirow{2}{*}{$\begin{array}{l}\text { Spot } \\
\text { no. }\end{array}$} & \multirow[b]{2}{*}{ Name } & \multirow{2}{*}{$\begin{array}{l}\text { Accession } \\
\text { no. }\end{array}$} & \multirow{2}{*}{$\begin{array}{l}\text { No. of } \\
\text { peptides* }\end{array}$} & \multirow{2}{*}{$\begin{array}{l}\text { Sequence } \\
\text { coveraget (\%) }\end{array}$} & \multirow[b]{2}{*}{ Scoreł } & \multicolumn{4}{|c|}{ Ratio of relative abundance§ } \\
\hline & & & & & & IL/NLף & $15 / N 5^{* *}$ & I5/IL & $\mathrm{N} 5 / \mathrm{NL}$ \\
\hline 7 & $\begin{array}{l}\text { Putative 3-beta hydroxysteroid } \\
\text { dehydrogenase/isomerase protein } \\
\text { [Arabidopsis thaliana]. AAM61751 }\end{array}$ & gi|34897418 & 3 & 14 & 213 & NS & $2.76 \pm 0.03$ & $1.95 \pm 0.18$ & NSt† \\
\hline 8 & $\begin{array}{l}\text { Stromal ascorbate peroxidase } \\
\text { [Oryza sativa (japonica cultivar-group)] }\end{array}$ & gi|32879781 & $1 \neq \ddagger$ & 2 & 45 & NS & $5.41 \pm 0.87$ & $3.27 \pm 1.27$ & NS \\
\hline 9 & $\begin{array}{l}\text { Putative chitinase [Oryza sativa } \\
\text { (japonica cultivar-group)] }\end{array}$ & gi|55168113 & $1 \S \S$ & 4 & 55 & NS & $4.79 \pm 2.44$ & $2.77 \pm 1.70$ & NS \\
\hline 10 & $\begin{array}{l}\text { Putative chitinase [Oryza sativa } \\
\text { (japonica cultivar-group)] }\end{array}$ & gi|55168113 & 4 & 21 & 179 & NS & $2.91 \pm 0.20$ & $2.00 \pm 0.30$ & NS \\
\hline 11 & $\begin{array}{l}\text { Glyceraldehyde 3-phosphate dehydrogenase } \\
\text { A subunit [Arabidopsis thaliana] }\end{array}$ & gi|166702 & 5 & 10 & 168 & NS & $2.76 \pm 0.60$ & $1.87 \pm 0.50$ & NS \\
\hline 12 & $\begin{array}{l}\text { Putative alpha } 1 \text { subunit of } 20 \text { S proteasome } \\
\text { [Oryza sativa (japonica cultivar-group)] }\end{array}$ & gi|50920359 & 4 & 15 & 173 & NS & $3.98 \pm 0.98$ & $2.44 \pm 0.06$ & NS \\
\hline 13 & $\begin{array}{l}\text { Ribulose-1,5-bisphosphate carboxylase/ } \\
\text { oxygenase activase [Oryza sativa] }\end{array}$ & gi|1778414 & 2 & 4 & 70 & NS & $3.91 \pm 1.01$ & $3.03 \pm 0.94$ & NS \\
\hline 14 & $\begin{array}{l}\text { Ribulose bisphosphate carboxylase } \\
\text { large chain (RuBisCO large subunit) }\end{array}$ & gi|6093918 & 1११ & 2 & 53 & NS & $5.19 \pm 0.10$ & $3.12 \pm 0.18$ & NS \\
\hline 15 & $\begin{array}{l}\text { Putative chaperonin } 60 \text { beta precursor } \\
\text { [Oryza sativa (japonica cultivar-group)] }\end{array}$ & gi|34897924 & 10 & 21 & 687 & NS & $0.67 \pm 0.10$ & $1.94 \pm 0.20$ & $3.20 \pm 0.20$ \\
\hline 16 & 14-3-3-like protein [Oryza sativa] & gi|7271253 & 4 & 17 & 190 & NS & $0.60 \pm 0.06$ & NS & $1.55 \pm 0.08$ \\
\hline 17 & $\begin{array}{l}\text { Endosperm lumenal binding } \\
\text { protein [Oryza sativa] }\end{array}$ & gi|2267006 & 9 & 16 & 299 & NS & $0.65 \pm 0.01$ & $1.82 \pm 0.17$ & $2.30 \pm 0.30$ \\
\hline
\end{tabular}

*Number of peptides identified from MS/MS spectra.

tPercentage of sequence coverage of identified peptides for protein.

$\ddagger$ Score $=-10 \times \log (P)$, where $P$ is the probability that the observed match with a given MS/MS spectra is a random event. Thus, a high score indicates identity or extensive homology.

$\S$ Ratios of relative abundance are presented as means $\pm S D(n=2)$. The ratios were calculated by dividing the relative abundance of a protein spot in one treatment by the relative abundance of a protein spot in the corresponding treatment. A value greater than 1 represents an increased protein, whereas a ratio less than 1 represents a decreased protein.

IIL, inoculated Labelle; NL, non-inoculated Labelle.

**I5, inoculated LSBR-5; N5, non-inoculated LSBR-5.

††NS, non-significant.

$\ddagger \ddagger$ Amino acid sequences: KYAEDQEAFFKD.

$\S \S A$ mino acid sequences: RVLVGVVASPEADRD.

१९Amino acid sequences: KLTYYTPEYETKD.

The 16 additional proteins identified in this study have been previously reported to be involved in antifungal activity, signal transduction, energy metabolism, photosynthesis, protein folding and degradation, signal transduction, and antioxidation (Asada, 1992; Broglie et al., 1991; Finnie et al., 2002; Lorimer, 1996; Shen et al., 2003; Umeda and Uchimiya, 1994). For example, two different protein spots were identified as putative chitinases that were increased only in the resistant line. Chitinase, referred to as PR-3, catalyses the hydrolysis of $\beta$-1-4-linkage of the $N$-acetylglucosamine polymer of chitins, a major component of fungal cell walls (Lin et al., 1995). $\beta-1,3$-glucanase was also found in the current study to be up-regulated to a higher level in the resistant vs. susceptible line after challenge by $R$. solani. $\beta$-1,3-glucanase, referred to as PR-2, is a hydrolytic enzyme commonly found in plants that hydrolyses $\beta$-1,3-linked glucans, the major component of fungal cell walls (Van Loon et al., 1987; Yamaguchi et al., 2002). Consistent with this study, Bera and Purkayastha (1997) showed that $\beta$-1,3-glucanases and chitinase were induced upon infection with $R$. solani. In addition to pathogen attack, $\beta-1$, 3 -glucanase was reported to be induced by various defencesignalling molecules such as $S A$, methyl jasmonate and ethylene (Linthorst et al., 1990; Mauch and Staehelin, 1989; Rickauer et al., 1997). Chitinase and $\beta-1,3-$ glucanase can synergistically inhibit fungal growth in vitro, and the coexpression of these two enzymes was shown to enhance resistance against $R$. solani significantly in transgenic rice (J. K. Kim et al., 2003; Mauch et al., 1988). This synergetic effect may have contributed to the high resistance levels of LSBR- 5 evaluated in our proteomic research. 

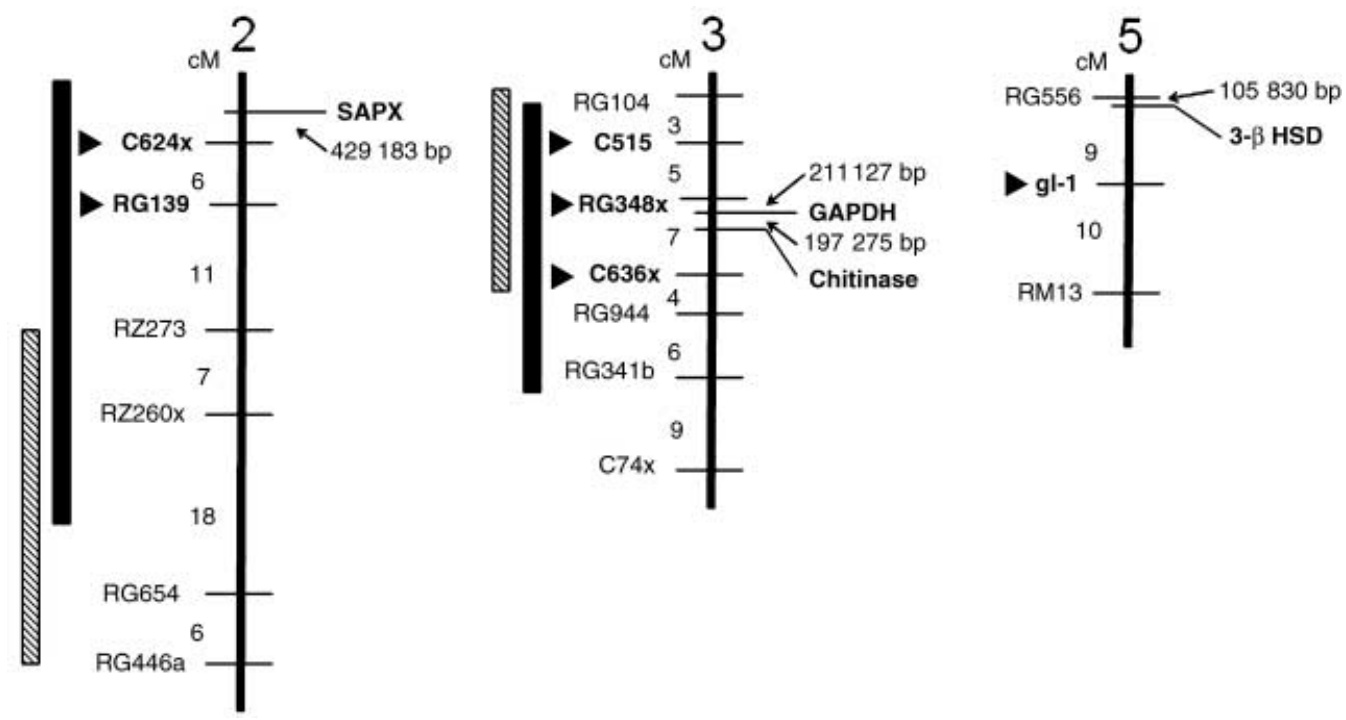

Fig. 4 Composite genetic and physical maps for QTL regions and DNA markers on chromosomes 2, 3 and 5 associated with sheath blight disease resistance and proteins detected in this study. Left side of chromosome shows QTL regions and genetic distance between markers in Kosambi map units (cM). Right side of chromosome shows proteins detected in this study and their physical distance to DNA markers in base pairs obtained from the Gramene website (http://www.gramene.org/). QTLs for sheath blight resistance identified by Li et al. (1995) using $F_{4}$-bulked lines from Lemont $\times$ Teqing cross. QTLs for sheath

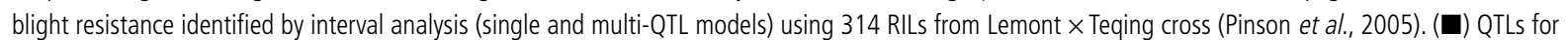
sheath blight resistance identified by Li et al. (1995) using $\mathrm{F}_{4}$-bulked lines from Lemont $\times$ Teqing cross. ( $\mathbb{N}$ ) QTLs for sheath blight resistance identified by interval analysis (single and multi-QTL models) using 314 RILs from Lemont $\times$ Teqing cross (Pinson et al., 2005). Markers identified by Pinson, Oard and Capdevielle (unpublished data) and unpublished results using discriminant analysis and step-wise multiple regression. SAPX, stromal ascorbate peroxidase; GAPDH, glyceradehyde 3-phosphate dehydrogenase; 3- $\beta$ HSD, 3- $\beta$-hydroxysteriod dehydrogenase/isomerasae; $g /$-1, phenotypic marker for glabrous leaf.

SAPX was increased only in the resistant line during our studies. Ascorbate peroxidase (APX) scavenges superoxide, hydroxyl radicals and singlet oxygen in the cytosol, chloroplast and mitochondria of higher plants. APX uses two molecules of ascorbate, the most important antioxidant substrate in plants, to reduce $\mathrm{H}_{2} \mathrm{O}_{2}$ to water (Asada, 1992). Decline of the SAPX protein level was detected in viral infected tobacco during programmed cell death (PCD), known as the hypersensitive response (HR) in plants (Mittler et al., 1998). Suppression of APX proteins supposedly contributes to PCD by allowing $\mathrm{H}_{2} \mathrm{O}_{2}$ accumulation in the cells (Mittler et al., 1998). The opposite results in our study, where SAPX proteins were increased in LSBR- 5 and Labelle, suggest that the harvested leaf sheaths, without necrosis or injury of any kind, did not produce a PCD response.

A protein spot identified as homologous to GAPDH A subunit isoform from Arabidopsis was increased only in the resistant line. GAPDH plays an important role in glycolysis and gluconeogenesis by reversibly catalysing the oxidation and phosphorylation of glyceraldehyde-3-phosphate to 1,3-bisphosphoglycerate, a high-energy intermediate used for the synthesis of ATP with a cosubstrate of $\mathrm{NAD}^{+}$(Umeda and Uchimiya, 1994). GAPDH is known to be induced by anaerobic conditions (Sachs et al., 1996). GADPH was induced in potato leaves and stems by infection of the late-blight fungal pathogen Phytophthora infestans, by treatment of eicosapentaenoic acid (an elicitor found in $P$. infestans) or by exogenous SA, a signal molecule inducing systemic acquired resistance (SAR) (Laxalt et al., 1996). These reports of GADPH induction under various environmental conditions, including abiotic and biotic stress, suggest that the GADPH metabolism pathway plays multiple roles in the plant cell or that related multiple defence pathways are regulated by similar signal transduction pathways (Laxalt et al., 1996).

The $26 \mathrm{~S}$ proteasome was increased in both the resistant and the susceptible lines with a higher expression ratio detected in the mutant vs. the susceptible wild-type. The $26 \mathrm{~S}$ proteasome plays an essential role in the ubiqutin/26S proteasome-mediated ATP-dependent proteolysis system in which proteolysis is specific and strictly controlled (Vierstra, 2003). Plants respond to the various environmental changes by expressing new proteins as well as degrading regulatory proteins, damaged proteins, and proteins that may become useless in a new environment. The ability to switch from one physiological mode to another is essential for the growth of plants that cannot move away from unfavourable environments (Basset et al., 2002). The induction of the $26 \mathrm{~S}$ proteasome in both LSBR-5 and Labelle implies that the physiological status of both resistant and susceptible lines was shifted 
to a defence mode. However, resistance of the somaclonal mutant is attributed to production of adequate amounts of the protein to mount a resistant response.

The 20 s proteasome $\beta$ subunit was increased in both the resistant and the susceptible lines of our study, where the expression ratio in the mutant line was higher than in the susceptible line. A putative $\alpha 1$ subunit of 205 proteasome was increased only in the resistant line. The $20 \mathrm{~S}$ proteasome, the proteolytic core of the 26 proteasome, is known to be involved in the degradation of proteins modified by oxidation (Grune et al., 1995). In mammalian cells, the 205 proteasome has been shown to recognize and selectively degrade proteins damaged by oxidation, such as $\mathrm{H}_{2} \mathrm{O}_{2}$-modified haemoglobin (Giulivi et al., 1994). The upregulation of 205 proteasome in this study may be involved in the defence against oxidative stress, consistent with the induction of SAPX, an antioxidant protein, observed during our research.

The RuBisCO large subunits were increased in both the resistant and the susceptible lines of our study, where the expression ratio in the mutant line was higher than in the susceptible line. RuBisCO activase, the enzyme catalysing the activation of RuBisCO (Portis, 1990), was increased only in the resistant line. The level of RuBisCO proteins, a crucial enzyme for photosynthesis, is known to be reduced in infected plant cells because pathogens attack chloroplasts that lead to their degradation (Agrios, 1997). In recent rice proteomic research, however, RuBisCO proteins were reported to be increased in the rice leaf sheath by wounding stress (Shen et al., 2003). The induced level of RuBisCO proteins in the response of LSBR- 5 and Labelle may be explained by the unique area of harvested rice leaf sheath samples. Protein samples were extracted from the cells adjacent to the infected cells in our study to avoid contamination with fungal mycelia. Because the sampled leaf sheaths were not chlorotic and were green in colour, it is possible that the chloroplasts of the sampled cells were not yet directly affected by the infection, and photosynthetic activity was increased to compensate for loss in adjacent infected cells.

The 14-3-3 protein was decreased only in the resistant line after infection by the sheath blight fungus. The 14-3-3 protein is a phosphoserine-binding protein that regulates various target proteins by direct protein-protein interactions (Roberts, 2003). In plants, the 14-3-3 protein affects the activity of various enzymes and ion channels. For example, nitrate reductase and plasma membrane $\mathrm{H}+$ pumping ATPase are inhibited and activated, respectively, by the direct interaction with 14-3-3 proteins (Comparot et al., 2003; Kinoshita and Shimazaki, 1999). In the incompatible interaction in barley with an avirulent strain of the powdery mildew fungus, the 14-3-3 protein and plasma membrane $\mathrm{H}+$ ATPase were induced in epidermal cell layers, site of the $H R$, which causes localized sudden death in infected host cells to prohibit further pathogen invasion (Finnie et al., 2002). Zhou et al. (2000) proposed an HR model during the barley-powdery mildew interaction in which $\mathrm{H}+$ ATPase is activated in the epidermal cell by the detection of the avirulent pathogen, causing acidification in the apoplast. This low $\mathrm{pH}$ is optimal for oxalate oxidase, an enzyme used in plants to generate $\mathrm{H}_{2} \mathrm{O}_{2}$. The down-regulation of the 14-3-3 protein in our study suggests that the response of LSBR-5 is not consistent with the barley HR model. However, the 14-3-3 protein may have actually been induced either before or after the time of leaf sheath sampling in our study.

The induction of SAPX and 20S proteasome in our study, presumably to reduce host cell oxidative stress, may have accompanied the down-regulation of the 14-3-3 protein. As pointed out by Wan et al. (2002), production and removal of $\mathrm{H}_{2} \mathrm{O}_{2}$ must be strictly controlled during SAR because $\mathrm{H}_{2} \mathrm{O}_{2}$ acts not only as an antimicrobial compound and a signal molecule to induce defence proteins, but also as a toxic molecule to host plants. Thus, down-regulation of the 14-3-3 protein at the 24-h sampling time was consistent with induction of SAPX and 205 proteasome in LSBR-5 to reduce toxic effects of $\mathrm{H}_{2} \mathrm{O}_{2}$.

The chaperonin $60 \beta$ precursor was decreased in this study only in the resistant line. Chaperonin is known to be a stressrelated protein that binds particularly to denatured proteins to prevent degradation and to assist in protein refolding of ATP (Rochester et al., 1986). In eubacteria and eukaryotic organelles, chaperonin 60 is presumably involved in numerous enzymefolding functions (Lorimer, 1996). In plant chloroplasts, the level of chapronin 60 , being involved in assembly of RuBisCO holoenzyme, is normally coordinated with that of RuBisCO (Avni et al., 1989). However Holland et al. (1998) reported that the accumulation of chapronin 60 was detected in $N$. tabacum seedlings by salt, cold or prolonged darkness whereas the RuBisCO large subunit was decreased. This negative correlation suggests the possible role of chapronin 60 in stress responses. In our study, a slight reduction of the putative chaperonin 60 beta precursor was detected with induction of RuBisCO proteins in the response of LSBR-5 to R. solani.

The luminal-binding protein (LBP) was found to be decreased only in the resistant somaclonal line. This protein is reported to be involved in folding and synthesis of defence-related proteins produced in the rough endoplasmic reticulum (ER) (Jelitto-Van Dooren et al., 1999). In tobacco, LBP was induced rapidly in response to attack by Erwinia carotovora, reaching a maximum accumulation $2 \mathrm{~h}$ after inoculation. It is unknown how downregulation of ER chaperones is related to the defence response in rice, but it has been reported that calreticulin in the endoplasmic reticulum, a $\mathrm{Ca}^{2+}$ binding protein that has molecular chaperone function, was down-regulated in the rice leaf sheath by wounding stress (Shen et al., 2003).

Results from our proteomic study suggest that the response of rice to challenge by $R$. solani involved the recruitment of proteins from various defence pathways. Several of the proteins detected in the current study were previously reported to be expressed by 
various pathogen treatments as well as various abiotic stresses, suggesting that some common response pathways exist in the rice defence system. Based on results from this study, the rice response to $R$. solani may be described where energy required to induce a defence was supplied by proteins involved in energy metabolism (GAPDH, RuBisCO), and the physiological status of infected rice was shifted to a defence mode via induction of the proteolytic enzymes 265 proteasome and 205 proteasome. The host response to infection was characterized by induction of the antioxidant protein SAPX accompanied by a slight reduction in the $\mathrm{H}_{2} \mathrm{O}_{2}$-inducing 14-3-3 protein that protected plant cells from oxidative stress. The antifungal proteins chitinase and glucanase were used directly to attack and degrade cell walls of $R$. solani.

Although we detected differences between the resistant and susceptible lines with the 2-DE PAGE approach, the proteome evaluated in our study was focused within a $\mathrm{pH}$ range of $4-7$ and at a single time point $24 \mathrm{~h}$ post-inoculation. Multidimensional separation techniques such as MudPIT (Link et al., 1999), coupled with multiple time points for tissue sampling, will be required in future studies to identify additional low-abundance, basic, hydrophobic or membrane-bound proteins associated with resistance to $R$. solani.

\section{Comparative analysis between proteomics approach and genetic analysis}

Results from our proteomic and genetic studies suggest that the identified proteins play a role(s) in the defence mechanism of rice when challenged by $R$. solani. Figure 4 shows the genomic location of genes encoding the induced proteins SAPX, chitinase, GAPDH and 3- $\beta$ HSD, and their relationships among the identified QTL regions and selected DNA markers believed to be associated with sheath blight resistance. Consistency between the proteomic and genetic data obtained from this study enhances confidence in the identity of proteins involved in sheath bight resistance and demonstrates the potential value of combining different technologies to address questions not possible by a single approach. It will be of value to conduct further comparison analyses among all detected proteins in our study and various QTL for defence against biotic and abiotic stresses. Results from this study are the first to demonstrate a correspondence between genetic and proteomic approaches for resistance to $R$. solani, which supports the suggestion that proteomics can be combined with genetic analysis to provide 'a clue for explaining QTLs' (Prioul et al., 1999).

\section{EXPERIMENTAL PROCEDURES}

\section{Plant material and inoculation}

Seeds from susceptible Labelle and resistant LSBR-5 were sterilized in $50 \%$ bleach, rinsed with water and geminated in
Petri dishes at $28^{\circ} \mathrm{C}$ in the dark. Three individual germinated seeds per line were placed in a single pot $16 \mathrm{~cm}$ in diameter and grown in the greenhouse under natural light conditions for 6 weeks before inoculation. Temperature of the greenhouse was $\sim 30^{\circ} \mathrm{C}$ during the day and $\sim 22^{\circ} \mathrm{C}$ at night. Six pots were prepared for each line, with three pots for the inoculated treatment and three for the non-inoculated treatment.

A modified inoculation method based on that of Singh et al. (2002) was used, in which $R$. solani strain LR 172 was grown on potato dextrose agar (DIFCO, Franklin Lakes, NJ) for 4 days at $28^{\circ} \mathrm{C}$ in the dark to produce white, compact, immature sclerotia, $\sim 1 \mathrm{~mm}$ in diameter. A rice leaf sheath from a 6 -week-old plant at the late tillering stage was opened gently to expose a stem. A single sclerotium was placed beneath the leaf sheath and $\sim 50 \mu \mathrm{L}$ of sterilized water was added. Leaf sheaths of control noninoculated plants were opened slightly, and sterilized water was added. After inoculation, plants were placed in a home-made humidifier chamber $(130 \mathrm{~cm}$ long, $115 \mathrm{~cm}$ wide, $115 \mathrm{~cm}$ high, containing $150 \mathrm{~L}$ of water, covered with $0.03-\mathrm{mm}$-thick plastic) at 17:00 $\mathrm{h}$ for $24 \mathrm{~h}$ to maintain $\sim 100 \%$ humidity on the leaves. To reduce plant stress caused by constant heat and humidity, the plastic was removed from the chamber the following morning at 08:00 h for $10 \mathrm{~min}$.

Two separate experimental (biological) replications were carried out in this study where each replication consisted of four treatments: inoculated LSBR-5, non-inoculated LSBR-5, inoculated Labelle and non-inoculated Labelle. For each treatment, one pooled protein sample was created by extracting and combining proteins from treated leaf sheaths of 7-9 plants. The pooled protein sample was distributed equally among three aliquots, which served as subreplications of the pooled protein sample. Thus, this experimental design consisted of two biological replications, four treatments and three subreplications nested within the treatments.

\section{Protein extraction and 2-DE PAGE}

After $24 \mathrm{~h}$ of incubation in the plastic chamber, inoculated leaf sheaths showed typical disease lesions. To determine the appropriate tissue for harvest that did not contain mycelia of $R$. solani, inoculated leaf sheaths were stained in five separate experiments with Trypan Blue (Sigma, St Louis, MO) (Frye and Innes, 1998) that showed mycelia were not detected $\sim 2 \mathrm{~cm}$ above the lesion formed $24 \mathrm{~h}$ after inoculation (data not shown). Therefore, to avoid contamination with $R$. solani, $3 \mathrm{~cm}$ of leaf sheath tissue was harvested $2 \mathrm{~cm}$ above the lesion. The harvested leaf sheath samples were immediately placed on dry ice and then stored at $-80^{\circ} \mathrm{C}$ until protein extraction. The protein extraction method was based on that of Koller et al. (2002) with some modifications. Briefly, frozen leaf sheaths were ground in a mortar with liquid nitrogen and suspended in 10\% TCA in acetone with $0.07 \%$ DTT 
at $-20^{\circ} \mathrm{C}$ for $1 \mathrm{~h}$, followed by centrifugation for $15 \mathrm{~min}$ at $35000 \mathrm{~g}$. The pellets were washed once with ice-cold acetone containing $0.07 \%$ DTT at $-20^{\circ} \mathrm{C}$ for $1 \mathrm{~h}$ and centrifuged again for $15 \mathrm{~min}$ at $35000 \mathrm{~g}$. This washing step was repeated $4-5$ times until the supernatant was clear. The final precipitated pellets were freeze-dried in an AdVantage Freeze Dryer (VirTis, Gardiner, NY). A total of $10 \mathrm{mg}$ of the dried powder was dissolved in $350 \mu \mathrm{L}$ of buffer containing $7 \mathrm{~m}$ urea, $2 \mathrm{~m}$ thiourea, $4 \%$ CHAPS, $0.5 \%$ ampholytes (pH 3-10) and $0.7 \%$ DTT. The powder dissolved in the extraction buffer was gently shaken for $1 \mathrm{~h}$, and then centrifuged for $30 \mathrm{~min}$ at $35000 \mathrm{~g}$ at room temperature. The supernatant was distributed in $100-\mu \mathrm{L}$ aliquots and kept at $-80^{\circ} \mathrm{C}$ until 2-D PAGE analysis. A total of $100 \mu \mathrm{g}$ of protein, assayed by PlusOne ${ }^{\mathrm{TM}}$ 2-D Quant Kit (Amersham Biosciences, Piscataway, NJ), was loaded on to a 17-cm linear IIPG strip (Bio-Rad). The first dimensional electrophoresis (isoelectric focusing) was carried out with a Protein Isoelectric Focusing Unit (Bio-Rad) according to the manufacturer's instructions. The second dimensional electrophoresis was conducted on $12 \%$ polyacrylamide LDS (lithium-dodecyl sulphate) gels using Bio-Rad Protein II XL Gel Cell (Bio-Rad). The second electrophoresis running conditions were as follows: constant $16 \mathrm{~mA}$ for $30 \mathrm{~min}$ at $6^{\circ} \mathrm{C}$ followed by constant $30 \mathrm{~mA}$ per gel until the BPB dye reached the bottom of the gel. The 2-D gels were stained with Sypro-Ruby (Bio-Rad), and images were acquired using an FX scanner (Bio-Rad).

\section{Image analysis}

Spot detection and matching analysis were conducted first with the PDQUEST program (Bio-Rad) and then manually checked a second time. The normalized protein spot quantity was obtained by dividing the quantity of a spot with the total spot quantities over the whole gel. Only those spots presented in all of the gels used in our experiment were used in the statistical analysis. Owing to our experimental design, which has two biological replications and three subsampling replications nested into each biological replication, the ANOVA of nested design was used to detect protein spots showing statistical difference in abundance between treatments. Thus, the protein spots described in this study showed statistical significance and reproducibility across experiments.

\section{Protein digestion}

Using the ProteomeWork gel cutter (Bio-Rad), protein spots were excised from the Sypro-Ruby- (Bio-Rad) stained preparative gels in which $300 \mu \mathrm{g}$ of proteins of inoculated LSBR-5 were loaded. Six preparative gels were used to obtain sufficient amounts of protein for identification. The excised protein spots were digested with trypsin using the MassPREP station (Waters). The excised spots were de-stained with $50 \mu \mathrm{L}$ of $50 \mathrm{~mm}$ ammonium bicarbonate and $50 \mu \mathrm{L}$ of $50 \%$ acetonitrile, washed once with $50 \mu \mathrm{L}$ of $100 \mathrm{~mm}$ ammonium bicarbonate, and then dehydrated with $50 \mu \mathrm{L}$ of acetonitrile. The in-gel protein was reduced and alkylated by incubation for $30 \mathrm{~min}$ at $56^{\circ} \mathrm{C}$ with $10 \mathrm{~mm}$ dithioreitol/ $100 \mathrm{~mm}$ ammonium bicarbonate. This reducing solution was then replaced with $55 \mathrm{~mm}$ iodoacetamide/100 mm ammonium bicarbonate followed by incubation of protein for $30 \mathrm{~min}$ at room temperature. Digestion was carried out with $6 \mathrm{ng} / \mu \mathrm{L}$ trypsin in $25 \mu \mathrm{L}$ of $50 \mathrm{~mm}$ ammonium bicarbonate for $5 \mathrm{~h}$ at $37^{\circ} \mathrm{C}$. The digested protein was extracted twice, first with $30 \mu \mathrm{L}$ of $1 \%$ formic acid followed by $12 \mu \mathrm{L}$ of $1 \%$ formic acid $/ 50 \%$ acetonitrile.

\section{ESI-Q-TOF MS analysis}

The digested protein samples were introduced into a tandem mass spectrometer, Q-TOF Micro (Waters) equipped with a CapLC system (Waters) using the PepMap C18 analytical column (LC Packings, Amsterdam, The Netherlands) at a flow rate of $8 \mu \mathrm{L} /$ min. The linear gradient was initiated from $95 \% \mathrm{~A}\left(\mathrm{H}_{2} \mathrm{O} / 0.05 \%\right.$ $\mathrm{HCOOH}$ ) to $65 \% \mathrm{~B}$ (acetonitrile $/ 0.05 \% \mathrm{HCOOH}$ ) in $36 \mathrm{~min}$ followed by a linear gradient to $90 \%$ B in 2 min. MS/MS spectra were acquired by MassLynx software (Waters). The Q-TOF Micro's internal parameters were set with the electrospray capillary voltage at $3.0 \mathrm{kV}$, the cone voltage at $30 \mathrm{~V}$ and the source temperature at $80^{\circ} \mathrm{C}$. The MS survey scan was $\mathrm{m} / \mathrm{z} 300-1600$ with a scan time of $0.9 \mathrm{~s}$ and an interscan time of $0.1 \mathrm{~s}$. The minimum threshold intensity of a peak was 10 counts.

\section{Database searching with MS/MS spectra}

MS/MS spectra were used in protein identification using the Mascot MS/MS lon Search Engine (http://www.matrixscience.com/ search_form_select.html). The NCBI rice (Oryza sativa) nonredundant protein database was searched first, then the Viridiplantae database was searched if no significantly matched proteins were found or the matched rice proteins were classified as unnamed, unknown or hypothetical. The following search criteria were used: one missed cleavage, variable modifications of carbamidomethyl cystein and oxidation of methionine, $\pm 2.0 \mathrm{Da}$ peptide tolerance, and $\pm 0.8 \mathrm{Da} \mathrm{MS} / \mathrm{MS}$ tolerance.

\section{Location of genetic markers and induced proteins associated with sheath blight resistance on composite genetic/physical map}

QTL regions previously identified for sheath blight resistance among $\mathrm{F}_{4}$ families (Li et al., 1995) and recombinant inbred lines (Pinson et al., 2005) were placed on a composite genetic/ physical map and compared with markers selected by discriminant analysis/multiple regression (Pinson, Oard and Capdevielle, unpublished data) and proteins identified in this study (Fig. 4). 


\section{ACKNOWLEDGEMENTS}

We thank the Louisiana Rice Research Board for partial funding of this research. Additional support was provided to T.M.B. by grants from the National Science Foundation and the Department of Energy.

\section{REFERENCES}

Agrios, G.N. (1997) Plant Pathology, 4th edn. New York: Academic Press.

Asada, K. (1992) Ascorbate peroxidase—a hydrogen peroxide-scavenging enzyme in plants. Physiol. Plant. 85, 235-241.

Avni, A., Edelman. M., Rachailovich, I., Aviv, D. and Fluhr, R. (1989) A point mutation in the gene for the large subunit of ribulose 1,5bisphosphate carboxylase/oxygenase affects holoenzyme assembly in Nicotiana tabacum. EMBO J. 8, 915-1918.

Basset, G., Raymond, P., Malek, L. and Brouquisse, R. (2002) Changes in the expression and the enzymic properties of the 205 proteasome in sugar-starved maize roots. Evidence for an in vivo oxidation of the proteasome. Plant Phys. 128, 1149-1162.

Bera, S. and Purkayastha, R.P. (1997) Identification and characterization of some PR-proteins induced by kitazin and Rhizoctonia solani causing sheath blight of rice. Indian. J. Exp. Biol. 35, 644-649.

Broglie, K., Chet, I., Holliday, M., Cressman, R., Briddle, P., Knowlton, S., Mauvaism, C.J. and Broglie, R. (1991) Transgenic plants with enhanced resistance to the fungal pathogen Rhizoctonia solani. Science, 254, 1194-1197.

Comparot, S., Lingiah, G. and Martin, T. (2003) Function and specificity of 14-3-3 proteins in the regulation of carbohydrate and nitrogen metabolism. J. Exp. Bot. 54, 595-604.

Devos, M.K. and Gale, D.M. (2000) Genome relationships: the grass model in current research. Plant Cell, 12, 637-646.

Finnie, C., Andersen, C.H., Borch, J., Gjetting, S., Christensen, A.B., de Boer, A.H., Thordal-Christensen, H. and Collinge, D.B. (2002) Do 14-3-3 proteins and plasma membrane $\mathrm{H}+$-ATPases interact in the barley epidermis in response to the barley powdery mildew fungus? Plant Mol. Biol. 49, 137-147.

Finsterbusch, A., Lindemann, P., Grimm, R., Eckerskorn, C. and Luckner, M. (1999) $\Delta^{5}-3 \beta$-Hydroxysteroid dehydrogenase from Digitalis lanata Ehrh. a multifunctional enzyme in steroid metabolism? Planta, 209, 478-486.

Frye, C.A. and Innes, R.W. (1998) An Arabidopsis mutant with enhanced resistance to powdery mildew. Plant Cell, 10, 947-956.

Giulivi, C., Pacifici, R.E. and Davies. K.J.A. (1994) Exposure of hydrophobic moieties promotes the selective degradation of hydrogen peroxidemodified hemoglobin by the multicatalytic proteinase complex, proteasome. Arch. Biochem. Biophys. 311, 329-341.

Goff, S.A., Ricke, D., Lan, T.H., Presting, G., Wang, R., Dunn, M., Glazebrook, J., Sessions, A., Oeller, P., Varma, H., Hadley, D., Hutchison, D., Martin, C., Katagiri, F., Lange, B.M., Moughamer, T., Xia, Y., Budworth, P., Zhong, J., Miguel, T., Paszkowski, U., Zhang, S., Colbert, M., Sun, W., Chen, L., Cooper, B., Park, S., Wood, T.C., Mao, L., Quail, P., Wing, R., Dean, R., Yu, Y., Zharkikh, A., Shen, R., Sahasrabudhe, S., Thomas, A., Cannings, R., Gutin, A., Pruss, D., Reid, J., Tavtigian, S., Mitchell, J., Eldredge, G., Scholl, T., Miller, R.M., Bhatnagar, S., Adey, N., Rubano, T., Tusneem, N., Robinson, R., Feldhaus, J., Macalma, T., Oliphant, A. and Briggs, $S$.
(2002) A draft sequence of the rice genome (Oryza sativa L. ssp. japonica). Science, 296, 92-100.

Grune, T., Reinheckel, T., Joshi, M. and Davies, K.J. (1995) Proteolysis in cultured liver epithelial cells during oxidative stress. Role of the multicatalytic proteinase complex, proteasome. J. Biol. Chem. 270, 2344-2351.

Hiei, Y., Ohta, S., Kumari, T. and Kumashiro, T. (1994) Efficient transformation of rice (Oryza sativa L.) mediated by Agrobacterium and sequence analysis of the boundaries of the T-DNA. Plant J. 6, 271-282.

Holland, N., Belkind, A., Holland, D., Pick, U. and Edelman, M. (1998) Stress-responsive accumulation of plastid chaperonin 60 during seedling development. Plant J. 13, 311-316.

Hotta, Y., Tanaka, T., Bingshan, L., Takeuchi, Y. and Konnai, M. (1998) Improvements of cold resistance in rice seedlings by 5 -aminolevulinic acid. J. Pesticide Sci. 23, 29-33.

Imin, N., Kerim, T., Weinman, J.J. and Rolfe, B.G. (2001) Characterization of rice anther proteins expressed at the young microspore stage. Proteomics, 1, 1149-1161.

Jelitto-Van Dooren, E.P.W.M., Vidal, S. and Denecke, J. (1999) Anticipating endoplasmic reticulum stress: a novel early response before pathogenesis-related gene induction. Plant Cell, 11, 1935-1943.

Kim, J.K., Jang, I.C., Wu, R., Zuo, W.N., Boston, R.S., Lee, Y.H., Ahn, I.P. and Nahm, B.H. (2003) Co-expression of a modified maize ribosome-inactivating protein and a rice basic chitinase gene in transgenic rice plants confers enhanced resistance to sheath blight. Transgenic Res. 12, 475-484.

Kim, S.T., Cho, K.S., Yu, S., Kim, S.G., Hong, J.C., Han, C.D., Bae, D.W., Nam, M.H. and Kang, K.Y. (2003) Proteomic analysis of differentially expressed proteins induced by rice blast fungus and elicitor in suspensioncultured rice cells. Proteomics, 3, 2368-2378.

Kinoshita, T. and Shimazaki, K. (1999) Blue light activates the plasma membrane $\mathrm{H}^{+}$-ATPase by phosphorylation of the $\mathrm{C}$-terminus in stomatal guard cells. EMBO J. 18, 5548-5558.

Koller, A., Washburn, M.P., Lange, B.M., Andon, N.L., Deciu, C., Haynes, P.A., Hays, L., Schieltz, D., Ulaszek, R., Wei, J., Wolters, D. and Yates, J.R. (2002) Proteomic survey of metabolic pathways in rice. Proc. Natl Acad. Sci. USA, 99, 1969-1974.

Komatsu, S. and Tanaka, N. (2004) Rice proteome analysis: a step toward functional analysis of the rice genome. Proteomics, 5, 938-949.

Konig, A., Happle, R., Bornholdt, D., Engel, H. and Grzeschik, K.H. (2000) Mutations in the NSDHL gene, encoding a 3-beta-hydroxysteroid dehydrogenase, cause CHILD syndrome. Am. J. Med. Genet. 90, 339-346.

Konishi, H., Ishiguro, K. and Komatsu, K. (2001) A proteomics approach towards understanding blast fungus infection of rice grown under different levels of nitrogen fertilization. Proteomics, 1, 1162-1171.

Laxalt, A.M., Cassia, R.O., Sanllorenti, P.M., Madrid, E.A., Andreu, A.B., Daleo, G.R., Conde, R.D. and Lamattina, L. (1996) Accumulation of cytosolic glyceraldehyde-3-phosphate dehydrogenase RNA under biological stress conditions and elicitor treatments in potato. Plant Mol. Biol. 30, 961-972.

Lee, F.N. and Rush, M.C. (1983) Rice sheath blight: a major rice disease. Plant Dis. 67, 826-832.

Lin, W., Anuratha, C.S., Datta, K., Potrykus, I., Muthukrishnan, S. and Datta, S.K. (1995) Genetic engineering of rice for resistance to sheath blight. Bio/Technology, 13, 686-691.

Link, A.J., Eng, J., Schieltz, D.M., Carmack, E., Mize, G.J., Morris, D.R., Garvik, B.M. and Yates, J.R. 3rd (1999) Direct analysis of protein complexes using mass spectrometry. Nat. Biotechnol. 17, 676-682.

Linthorst, H.J.M., Melchers, L.S., Mayer, A., Van Roekel, J.S.C., 
Cornelissen, B.J.C. and Bol, J.F. (1990) Analysis of gene families encoding acidic and basic-1,3 glucanases of tobacco. Proc. Natl Acad. Sci. USA, 87, 8756-8760.

Lorimer, G.H. (1996) Molecular chaperones as facilitators of proteinfolding. Invest. Ophthalmol. Visual. Sci. 37, 1048-1048.

Maleck, K., Levine, A., Eulgem, T., Morgan, A. and Schmid, J. (2000) The transcriptome of Arabidopsis thaliana during systemic acquired resistance. Nat. Genet. 26, 403-410.

Marshall, D.S. and Rush, M.C. (1980) Infection cushion formation on rice sheaths by Rhizoctonia solani. Phytopathology, 70, 947-950.

Martel, J.W. and Malcolm, S.B. (2004) Density-dependent reduction and induction of milkweed cardenolides by a sucking insect herbivore. J. Chem. Ecol. 30, 545-561.

Mauch, F., Hadwiger, L.A. and Boller, T. (1988) Antifungal hydrolases in pea tissue. Purification and characterization of two chitinases and two $\beta-1,3$-glucanases differentially regulated during development and in response to fungal infection. Plant Physiol. 87, 325-333.

Mauch, F. and Staehelin, L.A. (1989) Functional implications of the subcellular localization of ethylene-induced chitinase and [beta]-1,3glucanase in bean leaves. Plant Cell, 1, 447-457.

Mittler, R., Feng, X. and Cohen, M. (1998) Post-transcriptional suppression of cytosolic ascorbate peroxidase expression during pathogen-induced programmed cell death in Tobacco. Plant Cell, 10, 461-473.

Nakashita, H., Yasuda, M., Nitta, T., Asami, T., Fujioka, S., Arai, Y., Sekimata, K., Takatsuto, S., Yamaguchi, I. and Yoshida, S. (2003) Brassinosteroid functions in a broad range of disease resistance in tobacco and rice. Plant J. 33, 887-898.

Nam, M.H., Heo, E.J., Kim, J.Y., Kim, S.I., Kwon, K.H., Seo, J.B., Kwon, O., Yoo, J.S. and Park, Y.M. (2003) Proteome analysis of the responses of Panax ginseng C.A. Meyer leaves to high light: use of electrospray ionization quadrupole-time of flight mass spectrometry and expressed sequence tag data. Proteomics, 3, 2351-2367.

Pan, X.B., Rush, M.C., Sha, X.Y., Xie, Q.J., Linscombe, S.D., Stetina, S.R. and Oard, J.H. (1999) Major gene, nonallelic sheath blight resistance from the rice cultivars Jasmine 85 and Teqing. Crop. Sci. 39, 338-346.

Pinson, S.R.M., Capdevielle, F.M. and Oard, J.H. (2005) Confirming QTLs and finding additional loci conditioning sheath blight resistance in rice using recombinant inbred lines. Crop Sci. 45, 503-510.

Portis, A.R. (1990) Rubisco activase. Biochim. Biophys. Acta, 1015, 15-28. Prioul, J.L., Pelleschi, S., Sene, M., Thévenot, C., Causse, M., de Vienne, D. and Leonardi, A. (1999) From QTLs for enzyme activity to candidate genes in maize. J. Exp. Bot. 50, 1281-1288.

Rakwal, R. and Agrawal, G.K. (2003) Rice proteomics: current status and future perspectives. Electrophoresis, 24, 3378-3389.

Rakwal, R. and Komatsu, S. (2000) Role of jasmonate in the rice (Oryza sativa L.) self-defense mechanism using proteome analysis. Elelctrophoresis, 21, 2492-2500.

Rheaume, E., Sanchez, R., Simard, J., Chang, Y.T., Wang, J., Pang, S. and Labrie, F. (1994) Molecular basis of congenital adrenal hyperplasia in two siblings with classical nonsalt-losing 3 beta-hydroxysteroid dehydrogenase deficiency. J. Clin. Endocrinol. Metab. 79, 1012-1018.
Rickauer, M., Brodschelm, W., Bottin, A., Veronesi, C., Grimal, H. and Esquerre-Tugaye, M.T. (1997) The jasmonate pathway is involved differentially in the regulation of different defense responses in tobacco cells. Planta, 202, 155-162.

Roberts, M.R. (2003) 14-3-3 proteins find new partners in plant cell signaling. Trends Plant Sci. 8, 218-223.

Rochester, D.E., Winer, J.A. and Shah, D.M. (1986) The structure and expression of maize genes encoding the major heat shock protein, hsp70. EMBO J. 5, 451-458.

Sachs, M.M., Subbaiah, C.C. and Saab, I.N. (1996) Anaerobic gene expression and flooding tolerance in maize. J. Exp. Bot. 47, 1-15.

Sasaki, T. and Burr, B. (2000) International Rice Genome Sequencing Project: the effort to completely sequence the rice genome. Curr. Opin. Plant. Biol. 3, 138-141.

Seidel, S., Kreis, W. and Reinhard, E. (1990) D5-3b-hydroxysteroid dehydrogenase D5/D4-ketosteroid isomerase (3b-HSD), a possible enzyme of cardiac glycoside biosynthesis, in cell cultures and plants of Digitalis lanata Ehrh. Plant Cell Report, 8, 621-624.

Shen, S., Jing, Y. and Kuang, T. (2003) Proteomics approach to identify wound-response related proteins from rice leaf sheath. Proteomics, 3 , 527-535.

Singh, A., Rohilla, R., Singh, U.S., Savary, S., Willocquet, L. and Duveiller, E. (2002) An improved inoculation technique for sheath blight of rice caused by Rhizoctonia solani. Can. J. Plant Pathol. 24, 65-68.

Umeda, M. and Uchimiya, H. (1994) Differential transcript levels of genes associated with glycolysis and alcohol fermentation in rice plants (Oryza sativa L.) under submergence stress. Plant Physiol. 106, 1015-1022.

Van Loon, L.C., Gerritsen, Y.A.M. and Ritter, C.E. (1987) Identification, purification and characterization of pathogenesis-related proteins from virus-infected Samsun NN tobacco leaves. Plant Mol. Biol. 9, 593-609.

Vidhyasekaran, P., Ponmalar, R.T., Samiyappan, R., Velazhahan, R., Vimala, R., Ramanathan, A., Paranidharan, V. and Muthukrishnan, S. (1997) Host-specific toxin production by Rhizoctonia solani, the rice sheath blight pathogen. Phytopathology, 87, 1258-1263.

Vierstra, R.D. (2003) The ubiquitin/26S proteasome pathway, the complex last chapter in the life of many plant proteins. Trends. Plant. Sci. 8, 135142.

Wan, J., Dunning, F.M. and Bent, A.F. (2002) Probing plant-pathogen interactions and downstream defense signaling using DNA microarrays. Funct. Integr. Genomics, 2, 259-273.

Xie, Q.J., Linscombe, S.D. and Rush, M.C. (1992) Registration of LSBR-33 and LSBR-5 sheath light-resistant germplasm lines of rice. Crop. Sci. 32, 507.

Yamaguchi, T., Nakayama, K., Hayashi, T., Tanaka, Y. and Koike, S. (2002) Molecular cloning and characterization of a novel $\beta-1,3-g l u c a n a s e$ gene from rice. Biosci. Biotechnol. Biochem. 66, 1403-1406.

Zhou, F.S., Andersen, C.H., Burhenne, K., Fischer, P.H., Collinge, D.B. and Thordal-Christensen, H. (2000) Proton extrusion is an essential signalling component in the HR of epidermal single cells in the barleypowdery mildew interaction. Plant J. 23, 245-254. 